\title{
Mogadishu as lost modern: In conversation with A Naked needle Ubah Cristina Ali Farah
}

\section{Prelude}

I met Nuruddin Farah for the first time in Rome: a city to which I had only recently moved. At the time I was only a student and the thought of becoming a writer had not yet even occurred to me. I am, for this reason, convinced that it was this first meeting with him and my passionate reading of all of his books that sparked an uncontainable inward desire to investigate, through literature, the tragedy that had befallen Somalia. Nuruddin chose not to leave the African continent; he chose, for many years, not to renounce his Somali passport courageously facing the never-ending interrogations, risks and humiliations faced by his countrymen at every border and transit point. My first novel began to take shape in response to a question that is posed by Nuruddin in Yesterday, Tomorrow: Voices from the Somali Diaspora. In his non-fiction book the obvious protagonist of the piece is the present: the point where the past converges with the foundations of the future. The present is represented in the title of the work by a comma: time in the balance; indefinite. Perhaps it is in the present that we might find the key to unlock the vicious circle in which Somalis and everyone who has had anything to do with them (especially Italy, the former colonial overlords of Southern Somalia) now find themselves entrapped. The present invites us to take responsibility for our actions and stop trying to pin the blame on others. My novel, Madre piccola is a story centred on the diaspora in which three narrative voices are intertwined. Each narrative voice tells its own story twice, once to an interlocutor from a shared cultural context and once to an interlocutor external to its cultural context. Nuruddin writes in Yesterday, Tomorrow: "Still, I must ask what becomes of a man or a woman upon whose sense of imaginative being, upon whose night, no moths taps at the window to the universe of his or her creativity?" (49) Put differently, how can a person who has lost all their points of reference re-root themselves after beginning a new life? The protagonists in Madre piccola are searching for the answer to this question in their relationships. Relationships are how we gauge our sense of ourselves and our way of being in the world; our most authentic identity. Nuruddin has never ceased to inspire me with his poetic instincts, his empathy and integrity, his deep reflections on the diaspora and the civil war, the central catastrophe of our history which is rarely spoken about among Somalis as though talking about it might bring on a curse. In Links, the author explains the Somali term for civil war in the form of a dialogue between two characters:

"In a civil war, death is an intimate," Af-Laawe said. "You're killed by a person with whom you've shared intimacies, and who will kill you, believing that he will benefit from your death. And when you think seriously about an entire country going up in civil-war flames, then you'll agree that "intimacy" is more complicated." [...]

"Do you know the Somali term for "civil war'?"

"Dagaalka sokeeye."

In his mind, Jeebleh couldn't decide how to render the Somali expression in English: in the end he preferred the notion of "killing an intimate" to "warring against an intimate." Maybe the latter described better what was happening in Somalia. $(137-8)$

The idea of the inherent intimacy of violence is extremely important. At this point, however, I would prefer to reflect on a different kind of intimacy: looking back at the past to cast new light on the present. What follows is an intimate dialogue with one of Nuruddin's first novels A Naked Needle, and a tourists' guide to Mogadishu to gain a fresh look at the Mogadishu of the 1970s.

Ubah Cristina Ali Farah is a Somali Italian poet and novelist. She writes full-time and has published two novels, Madre piccola and Il comandante del fiume. Email: crisubax@gmail.com

D0l: https://doi.org/10.17159/2309-9070/tvl.v.57i1.7984 


\section{Moviment \#}

"Dear guest, on behalf of the population of the city it is my pleasure to extend the warmest welcome and to wish you a pleasant stay in Mogadishu, Pearl of the Indian Ocean, Capital of the Democratic Republic of Somalia" (Giumale 4). These are the opening words to a bilingual guide of Mogadishu, published by Mohamed Sheikh Alì Giumale on behalf of the local government of Mogadishu in the early period of the regime of Muhammed Siyad Barre. More than forty years on, the formality of the address seems old-fashioned, yet the heartiness of the welcome is clear, "this guide is for you, appreciated guest of our city" (Giumale 12), and bathes us in a feeling of openness and hospitality. Similarly, Koschin, the protagonist of Farah's A Naked Needle, says to Nancy, his European fiancée who has just arrived after two years of separation: "It would be a very good idea, I think, if I took you round the wonderful city of Mogadiscio and showed you the treasures as well as the hidden infirmities of this ancient African settlement" (89). These are the years when Somalia first embraced the version of socialism introduced by Siyad Barre, "for which many Somalis perished", as Kaha Aden observes in her documentary La quarta via, MogadiscioItalia. Socialist Somalia was supposed to have created a break with colonialism and tribalism. "There is the Revolution to which I am loyal" writes Nuruddin on behalf of his character, Koschin, in the "Prelude" to A Naked Needle. And it was in this period, pregnant with hope, that my mother and I set foot in the country.

The first time that I saw Mogadishu I was only three years old—it was the summer of 1976. To be honest, I cannot remember anything about my mother's feelings on that occasion, but she must have been very moved, since it was also her first time in Mogadishu. I was born of a Somali father and an Italian mother in Verona. My parents were both students when they met. In the years to come, my mother often spoke about that arrival, she spoke about the language, perhaps in the hope that her recollections could, in part, be similar to mine. My father, on the contrary, never spoke about anything, perhaps because he knew that his recollections couldn't possibly be similar to mine. I said that I do not remember anything about my arrival, but in fact there is something that happened afterwards which is like a tiny ripple in my memory, something about the moment in which my first language mixed with the other language. They mixed so well that, if it were not for this vague recollection, I would think that the two languages had been born together inside me, like a single bush springing from two roots; iskadhal, this is what they call people like me in Somalia.

In this recollection, there is a small hedge, a hibiscus hedge, and behind the hedge one evening I hide, and I am alone in the house of my uncle Cali and my aunt Khadija. Alone-without my mother, I mean, and without my father, the ones who can understand me. My aunts and uncles are there, along with their six children and my grandmother Barni Xassan and a host of others. My cousins laugh; they don't laugh out of scorn, but I don't feel like laughing, I don't want to laugh, so I run and hide behind the hedge. "Come here", they say and I reply (in my mother tongue, which is not that of my father): "I understand nothing!" So my grandmother, who was with us that night, calls out to me, using a new name to soothe me, Ubax, flower, like the hibiscus blossoming on the hedge.

It's no coincidence, then, that this is the only recollection I have where the two languages are distinct-I understand one; I make no sense of the other: I shout out in one, but I'm a mute in the other-a single memory of me hiding behind a little hibiscus bush. "Why did you call your daughter Susan?" Koschin in A Naked Needle asks Mohamed, a friend who has married an American woman, speaking Somali. "We made a deal," he answers. "If a girl is born a Western name, if a boy is born a Somali name" (72).

A few months went by and then we moved to a home behind the Somali National Theatre: me, my mother, my father, his friend Cusman and my aunt Xamsa. The house behind the National Theatre stays with me today, with its small yard and its iron gate. One evening, my mother and I were coming back home in the dark. There can't have been a show on at the National Theatre that day, but I didn't know that as I was only three and still had many things to learn. As we got to the entrance, my mother realized that the gate was ajar, but she didn't have time to be frightened. She was frightened afterwards, when two rangy, dark men rushed out, wearing shirts and osgunti. They must have been two peasants, my father said later, otherwise they wouldn't have dared to scare a young Italian woman so near to the National Theatre, a dumashi (sister-in-law) with her daughter hiding away behind her legs.

I am not your brother-in-law. [Says Koschin to Barbara, an American married to a

Somali. ]

You cannot convince me you are not.

No need of proof. I'm not your husband's brother. 
Every Somali is either my brother-in-law or my sister-in-law, depending on the sex, depending on the sex of course, Take it or leave it.

I am not, I said. (59)

The two men had run off with only the living-room curtains, as there was nothing valuable in that first house where we had gone to live. Hiding behind my mother's legs, I had understood the language in which the two men spoke, and that of my mother, who was concealing me, this time hoping that I had different memories to hers.

Mogadishu was a seaside town, "stretched out along the coast" in the words of Kaha Mohamed Aden, a Somali political activist and writer based in Italy. "The revolutionary government is to be appreciated for the beautification and the modernization of the city with monuments for the dead, dignity for the living, bread for the bereaved and roads for the motorizzati" (A Naked Needle 94). One of the monuments referred to above was for Xawa Tako, the heroine who died on 11 January 1948 , and after whom my primary school was named. We all wore white and blue uniforms and sang hymns to the Revolution and when we came out of school, lots of us crowded round the wandering street-vendors, who, for a few kumi, dispensed sesame snaps and milk gums: "They deify the Old Man, [says Koschin,] sing his name to the skies. They make him into a God. [...] The Old Man is decent, honest, wishes to leave behind a name, wishes to do something for the country. [...] But it is his subalterns!" (80).

In hindsight, what struck me was how the town of Mogadishu was experienced by my mother, an Italian woman, as positively as she came to experience it. To my child's eye, she was always safe out on the streets of the cosmopolitan Mogadishu, both when in a shared taxi and when she drove her old, red Vespa some time later. One day she even asked a passer-by if she could take a photo of me beside him in front of the ancient Sheikh Abdulaziz mosque. The mosque stood not far from the Catholic Cathedral, where my mother would go every Sunday. In the years running up to the civil war, such a request would have been out of the question. "That dome, can't you see [says Nancy, Koschin's fiancée], the publicness of a church, the reverence and sacredness in the surroundings, the silence even, the quietness of a place of God?" (109).

Talking of taxis, they are easily distinguished by their yellow and red livery. The guide to Mogadishu is quite clear: "On no account should the fare exceed Som. Sh 20 within the city of Mogadishu. No tips are to be paid to taxi drivers, nor is anybody else entitled to a tip in the Democratic Republic of Somalia." (Giumale 12). The guide presents Mogadishu as a welcoming and predictable place. This definitely was how my mother experienced it.

There were always hordes of people at home, friends and relatives, some of whom stayed a short while, others stayed for longer periods. There is an exchange that takes place between Koschin and Barbara, the American wife of his friend, where Barbara relates the experience of the foreign wife, she refers to as "Vanity", of Barre, a man with whom she has had an affair:

What with the number of relations one has to be loyal to, the number of unwritten codes and laws a woman from a foreign land has to abide by, the dull life one has to lead, the rigid customs of this nomadic nation, Barre's dislike and Vanity's demands to go out to the movies together! On top of all this, Vanity couldn't bear living with her mother-in- law, and Barre's brothers and sisters who number over ten. (64)

In the recorded letters found in my grandmother's drawers back in Verona, my father's brother can be heard briefly greeting the family and describing my mother as follows, "The subject in question is a really kind young woman. We really like her." She was not perceived as the European wife and girlfriend represented in Somali plays, as the symbol of the danger and corruption of the West. She had become part of the family. Her experience was not the experience of the "foreign wives" (28) depicted in A Naked Needle. Here is Koschin speaking to his friend, Barre:

They make you cut off your ties with your brothers and sisters, they insinuate the idea from the moment they set their feet here that you must live your own life with them, without anyone ever coming to stay with you, without anyone ever freely dropping in to lunch or to tea any time any day as is our case. (28)

Even though many aspects of the city may have been unknown to my mother, Mogadishu was a cosmopolitan town which had adopted and "localized" different cultural habits and institutions. My mother would have been familiar with the custom of spending the evenings in the centre, with its more renowned cinemas and cafes, ordering macchiato or kabushiini. Bread was purchased at the bar-patisserie-restaurant-roofgarden-take-awaycheesemaker's-bakery called Azan, the only establishment that would even make fresh pasta to order. In those years I hadn't even heard of the Casa d'Italia, a club reserved for Italians, as was clear from the name. Just because 
he'd married a young Italian woman, it didn't mean that my father stopped being allergic to certain places linked to the colonial past. Nuruddin expresses it thus in A Naked Needle: "It is not decreed, of course, by the Mussolini leftovers that no native may apply and become a member of the club, but discrimination has its own subtleties -economic apartheid" (107).

If you wanted to see a film, the choice was more than ample, from the Cinema Centrale, the Equatore and Il Missione, as well as many others, all showing films directly in Italian. I preferred to go to the cinema with my cousins, rather than my parents: on Thursday evenings my uncle would take us all to see an Indian film. Obviously, he left us at the entrance and came back to pick us up when the film ended. Sentimental Bollywood love stories were not his thing. Our heroines were actresses with long, raven-black hair and the finest filigree jewellery, like the handmade jewellery of the artisans in the gold market. As Koschin points out to his fiancée, Nancy: "And that is Teatro Somalia which shows Hindi movies mainly, caters for the women-folk and the children-folk who adore Hindi movies" (97).

Occasionally, in the late afternoon, we'd go and watch my big cousin play tennis and we used to frown at her opponents in the vain belief that our eyes alone were enough to make them lose.

I can't tell how my mother lived in Mogadishu, because, as I mentioned, my recollections are undoubtedly different from hers, and then the final few years there greatly blurred the initial sensations. Perhaps the sea that she described is still the same, "without any beach parasols" and beautiful, despite the risk from sharks. "Unlike the overcrowded beaches in Europe and other countries in affluent society, here there is ample space for long walks without having to climb over other human bodies and without the threat of pollution" (Giumale 50). There is no doubt that the sea was the major element of my childhood: hours spent lying on the beach observing what the sea washed up, the futile begging with my aunt Xamsa, who was dead against sunbathing. In the early years, we used a beach cabin reserved for employees of the Somali Central Bank, where my uncle worked. The cabins were terraces overlooking the sea and there was a bar and changing rooms.

This is what Koschin tells Nancy about the banks in Mogadishu: "I found the banks pretty noisy. Instead of a congregation of businessmen in friendly dialogue, soft and whispering, very civil and sophisticated, here in the banks it was like a vegetable market in Southern Italy" (119). The Somali Central Bank was where letters for my mother arrived, given that P.O. boxes were in short supply at Mogadishu. "The Central Post Office, in Corso Somalia, is normally open from 07.00 to 12.30 and from 4 to 6pm every day except Friday, providing the following services: Air mail, Surface mail, Parcel post, Registered mail, Sale of stamps [...] Satellite telephone connection is available at the following time: Mogadishu—Rome (direct) from llam to 3pm" (Giumale 16). As you might imagine, the Mogadishu central post office played a key role in my mother's existence. I remember it as an imposing, saffron-coloured building with oleander bushes and yellow bellflowers outside the front. Climbing a short staircase, you entered the main hall, and this is where my mother used to sit with her long brown hair, waiting her turn after paying for her call in advance. (The choice was limited, either three, five, or at most, ten minutes). The operators would call out people's names when their turn came and then you would slide into the assigned cabin for the duration of the call. During this lengthy wait one day, I remember going outside to explore the garden. My father was there outside, chatting with a friend, who was wearing a long tunic, the baggy sleeves of which seemed empty. "Where are your arms?" I asked him in horror. "The shark ate them." he answered, "If you want, I'll show you the stumps." They both burst out laughing at the look of terror on my face. If, on the other hand, you wanted to send a letter or a card, or to view the latest issue of stamps, you had to go to the counters on the left: the young ladies were very polite and showed you splendid images of the flora and fauna of Somalia, as well as many other things too. In the building's lateral wings there were long rows of P.O. boxes, each one numbered. These were not individual and, as I mentioned above, our mail went to the P.O. Box of the Central Bank, where my uncle worked.

My grandmother in Italy used to send us all presents on special occasions. The opening of these parcels was a cause for great excitement at home. At the very moment the cardboard box was cut or torn open, a mysterious aroma emerged, a mix of strawberry and talcum powder, the smell of Italy. Once, my grandmother sent a musical box as a present. It was a little purple box covered in sateen. A ballerina in a pale pink tutu, wearing a diadem in the middle of her forehead, danced whilst looking at herself in a small, gold-framed mirror. The moment you opened the box, she began to revolve, dancing to the notes of Doctor Zhivago. It was monsoon season and her presence in my room seemed exotic and out of place. I loved her all the same.

In the decade before our arrival, the city had undergone major expansion and the Somali theatre was at the height of its splendour. This explosion peaked in 1967 with the inauguration of the Somali National Theatre, 
constructed under a Chinese cooperation programme. As a new art form, it perfectly met the demands of the newly urbanized population. Koschin informs Nancy on their walk through Mogadishu: "Housing capacity of the theatre is about three thousand, but at times when Baxsan, Marian Mursal, Hibo, Magol or the Moge Brothers take part in a play, some four or five thousand people are unkindly packed in" (103). It was the period when the best works were written, the most famous songs were to be heard and the most famous artists emerged. The new literary genre reached out to a vast public and supplanted the role formerly played by poetry in providing entertainment and cultural models, stimulating debate on contemporary issues such as colonialism, development, relations with the West and women's rights. The performances dramatized common desires and tensions, blurring the boundary between the self and the other, the self and the nation. These temporary arenas allowed the establishment of "communities of feeling" (Berezin 93), that created a sense of communality and belonging that called upon Somalis to embrace "soomaalinimo", a national Somali identity (Kapteijns 103). The Somali popular theatre was, from the very beginning, the expression of a new urban youth that saw Mogadishu as a place of promise, the desire for an optimistic urban future.

Whatever else cities may be, they almost always represent an aspiration, a desire for a better future. Exploitation, domination, poverty, malnutrition, and violence may be the daily reality for many city dwellers, but cities are also spaces of hope where millions of willing and unwilling migrants seek a better life (Prakash 499). Retrospectively some people try to deny that Mogadishu was this kind of modern cosmopolitan hopeful city. However, this is not correct and in this period it was popular culture that expressed some of the tensions that would prove so destructive later on and mediate them in a way that preserved the unity of the nation.

\section{Works Cited}

Berezin, Mabel. "Emotions and Political Identity: Mobilizing Affection for the Polity." Passionate Politics: Emotions and Social Movements, edited by Jeff Goodwin, James M. Jasper and Francesca Polleta. U of Chicago P, 2001.

Farah, Nuruddin. Links. Gerald Duckworth, 2005.

A Naked Needle. Heinemann, 1976.

Yesterday, Tomorrow: Voices from the Somali Diaspora. Cassell, 2000.

Giumale, Mohamed Sheikh Alì. Mogadishu. Perla dell'Oceano Indiano-Pearl of the Indian Ocean. P. Marzari Industrie Grafiche, n. d. Kapteijns, Lidwien, "Discourse on moral womanhood in Somali popular songs, 1960-1990." The Journal of African History vol. 50, no.1, 2007, pp. 101-22. DOI: https://doi.org/10.1017/s0021853708003927.

Prakash, Gyan. "Edward Said in Bombay." Critical Inquiry vol. 31, no. 2, 2005, pp. 498-504. DOI: https://doi.org/10.1086/430978. 